\title{
Skrifter udgivet af Grundtvig-Selskabet
}

I. Henning Høirup: Grundtvigs Syn paa Tro og Erkendelse. Gyldendal 1949. 420 sider. (Udsolgt.)

II. Helge Toldberg: Grundtvigs symbolverden. Gyldendal 1950. $\mathrm{XII}+356$ sider.

II. a. Helge Toldberg: Grundtvig som filolog. G. E. C. Gad 1946. 152 sider.

III. Magnus Stevns: Fra Grundtvigs Salmevarksted. Udgivet af Henning Høirup og Steen Johansen. Gyldendal 1950. (Udsolgt.)

IV. Villiam Grønbak: Psykologiske tanker og teorier hos Grundtvig. Gyldendal 1951. 192 sider.

V. Carl Weltzer: Grundtvig og Søren Kierkegaard. Gyldendal 1952. 96 sider.

VI. William Michelsen: Tilblivelsen af Grundtvigs historiesyn. Gyldendal 1954. 368 sider. (Udsolgt.)

VII. Henning Høirup: Fra døden til livet. Grundtvigs tanker om liv og død. Gyldendal 1954. 112 sider.

VIII. Niels Kofoed: Grundtvig som selvbiograf. Gyldendal 1954. 136 sider.

IX. William Michelsen: Den salsomme forvandling $i$ N. F. S. Grundtvigs liv. Gyldendal 1956. 288 sider.

X. N.F.S. Grundtvig: Taler paa Marielyst Højskole 1856-71, udgivet af Steen Johansen. Gyldendal 1956. 116 sider.

XI. Harry Aronson: Mänskligt och kristet. En studie $i$ Grundtvigs teologi. Bonnier 1960. 312 sider.

XII. Sigurd Aa. Aarnes: Historieskrivning og livssyn hos Grundtvig. Oslo 1962.

XIII. Kaj Thaning: Menneske forst-I-III. Gyldendal 1963.

XIV. Flemming Lundgreen-Nielsen: N. F. S. Grundtvig. Skabne og Forsyn. Gyldendal 1965. (Udsolgt.) 


\section{Grundtvig-Studier 1973}

er 26. bind af Grundtvig-Selskabets årsskrift

I 100-året for Grundtvigs død holdtes i Helsingør et internationalt seminar

\section{„A Century after Grundtvig”}

Hovedindholdet af dette bind er foredrag herfra, de tre første på dansk:

REGIN PRENTER

Om Grundtvigs tanker som en udfordring til moderne teologi.

HELLMUT TOF T D A H L

Eksistentialpsykologisk kritik af Grundtvig, set fra Søren Kierkegaards synspunkt.

\section{E J V I N D L A R S E N}

Konfrontation af Grundtvig og Marx, udførligt referat, samt et kapitel om Grundtvig og Shakespeare.

De øvrige foredrag er trykt efter forfatternes engelske manuskript med en forkortet gengivelse på dansk. Götz Harbsmeier viser, hvilken funktion Grundtvig kan have i Tyskland i dag. Tord Ehnevid sammenstiller hans historiesyn med Hegels, og Erica Simon gør opmærksom på ligheden mellem den nationale bevidstgørelse i Afrika i dag og 1800-tallets grundtvigske folkelighed. Højskolebevægelsens udvikling og status i dag er emnet for en række foredrag af Roar Skovmand, Thomas Rørdam, Sv. Erik Bjerre og Peter Manniche. I sit indledningsforedrag hævder Kaj Thaning, at Grundtvigs fundamentale problem var forholdet mellem menneskeliv og religion. De danske bidrag er refereret på engelsk.

HELE BOGEN KAN LASES SOM EN INTRODUKTION TIL GRUNDTVIG FOR MODERNE MENNESKER 